\title{
Assessment of Chromosomal Damage in Umbilical Blood Lymphocytes of Newborns from Kragujevac in Central Serbia Born 18 Years after Environmental Contamination
}

\author{
Olivera Milošević-Djordjevič, ${ }^{1,2}$ Jovana Tubić Vukajlović, ${ }^{1}$ Aleksandra Marković, ${ }^{1}$ \\ Darko Grujičić, ${ }^{1}$ Petar Arsenijević ${ }^{3,4}$ and Slobodan Arsenijević ${ }^{3,4}$

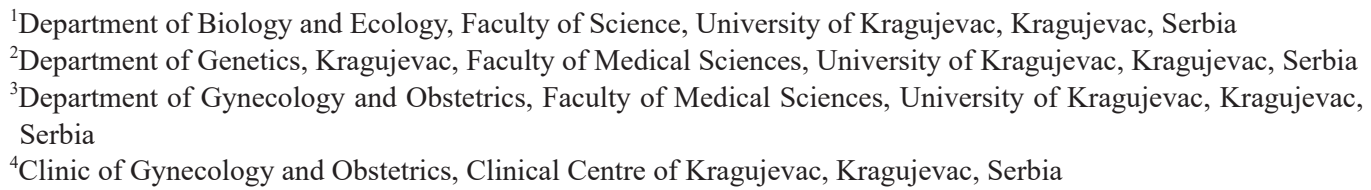

The measurement of micronuclei (MN) in umbilical blood lymphocytes of newborns are increasingly used in cytogenetic epidemiology as one of the preferred methods for assessing chromosomal damage resulted from maternal exposure to mutagen. In the present study, we evaluated the effect of strong environmental contamination (EC) (which occured in the City of Kragujevac, Central Serbia in 1999) on the MN frequency in group of 22 newborns born in Kragujevac 18 years after EC, using cytokinesis-block micronucleus (CBMN) assay. The mean MN frequency in umbilical lymphocytes of these newborns was $5.14 \pm$ $2.17 / 1,000$ binucleated $(B N)$ cells, which is significantly lower than mean MN frequency of newborns born 12 months after contamination (9.36 $\pm 5.60 / 1,000 \mathrm{BN}$ cells). Sex of newborns, age of mothers, cigarette smoking, and number of pregnancies did not affect the $\mathrm{MN}$ frequency of newborns. Our results showed that in utero exposure to environmental pollution affected genome instability of the fetuses, but that by improving the quality of environmental conditions there was a decrease in mean MN frequency of newborns born 18 years after contamination. In general, genome of umbilical lymphocytes shows a realistic picture of all changes in body and the environment.

Keywords: environmental contamination; micronucleus assay; newborns; umbilical blood lymphocytes Tohoku J. Exp. Med., 2021 November, 255 (3), 213-219.

\section{Introduction}

Industrial development and different lifestyles have improved the quality and way of life but have exposed the population to a variety of air, water and food borne toxic substances. Humankind faces daily exposure to a wide variety of toxic substances and complex mixtures of toxic pollutants which can induce negative effects at molecular, cellular, and physiological levels (Rollin 2011). Cumulative and synergistic activities of different pollutants are especially dangerous because they increase the risk to human health (Bakrac et al. 2018) and their physical and chemical properties can cause genotoxic effects (Dourado et al. 2017). Also, inhalation of particulate matter which contains metal, carcinogen organic and inorganic materials can cause DNA damage and genomic instability (Santibanez-Andrade et al. 2017). Thus, there is a growing concern in Serbia about the environmental pollution being among the leading causes of human diseases (Milic et al. 2019).

The exposure to a complex mixture of toxic pollutants can induce oxidative damage and promote the formation of micronuclei (MN) at the cellular level (O'Callaghan-Gordo et al. 2015). MN are defined as small extranuclear bodies that contain chromosome fragments or whole chromosomes that were not incorporated into the nucleus after cell division. The MN assay is reliable method for detecting chromosomal aberration and is frequently used for evaluation of genotoxicity due of its affordability and efficiency (Fenech 2020). Several studies have focused on the effect of expo-

Received July 20, 2021; revised and accepted August 17, 2021. Published online November 10, 2021; doi: 10.1620/tjem.255.213.

Correspondence: Olivera Milošević-Djordjević, University of Kragujevac, Faculty of Science, Radoja Domanovića 12, Kragujevac 34000, Serbia.

e-mail: olivera.djordjevic@pmf.kg.ac.rs

(C)2021 Tohoku University Medical Press. This is an open-access article distributed under the terms of the Creative Commons Attribution-NonCommercial-NoDerivatives 4.0 International License (CC-BY-NC-ND 4.0). Anyone may download, reuse, copy, reprint, or distribute the article without modifications or adaptations for non-profit purposes if they cite the original authors and source properly.

https://creativecommons.org/licenses/by-nc-nd/4.0/ 
sure to toxicants in order to induce increased MN frequency in human peripheral blood lymphocytes, especially in newborns (Stankovic et al. 2004; Milosevic-Djordjevic et al. 2005, 2007a; O'Callaghan-Gordo et al. 2015).

The most serious environmental contamination (EC) in Serbia occured during the NATO bombing on the Federal Republic of Yugoslavia, from March 24 to June 10, 1999. This EC had immediate regional and long-terms local consequences (Bakrac et al. 2018). The City of Kragujevac, located in Central Serbia, was exposed to constant air strikes, especially the car factory "Zastava", located on Lepenica River, a tributary of the Velika Morava River. The major problem in the City of Kragujevac was the leakage of several tons of polychlorinated biphenyls (PCBs) into the Lepenica River and groundwater pollution (UNEP 2000).

Our previous research showed that EC from 1999 caused significant increase in MN frequency in newborns born 12 months after EC and then decrease in newborns born 18 months after EC, comparing to the control samples born during 1998 in Kragujevac (Milosevic-Djordjevic et al. 2005). Milosevic-Djordjevic et al. (2007a) reported that newborns born seven years after EC had significantly lower MN frequency comparing to newborns born immediately after the EC. Stankovic et al. (2004) came to the similar results and showed increased $\mathrm{MN}$ frequency in umbilical blood lymphocytes of newborns born one and two years after the bombing of Serbia. Regarding these results and due to the long-term local consequences of EC in Serbia, especially in Kragujevac, the aim of this study was to evaluate $\mathrm{MN}$ frequency in umbilical blood lymphocytes of newborns born in Kragujevac 18 years after the EC.

\section{Material and Methods}

\section{Blood sampling}

The study included 22 healthy newborns ( 9 females and 13 males) recruited from the Clinic of Gynecology and Obstetrics of the Clinical Centre of Kragujevac, Republic of Serbia, in 2018, 18 years after EC (before COVID-19 epidemic). Samples of venous blood were collected by umbilical puncture from newborns whose mothers were not exposed to known mutagens or any therapy during the pregnancy. This study was approved by the Ethics Committee of the Clinical Centre of Kragujevac, Serbia (01/07-4899). General demographic characteristics of mothers were obtained and summarized in Table 1. Mothers were mean age of $28.59 \pm 4.56$ years, ranging from 21 to 36 years. Seven of 22 mothers were smokers.

\section{Cytokinesis-block micronucleus (CBMN) assay}

CBMN assay was carried out according to the method described by Fenech (2007). The heparinized blood samples $(0.5 \mathrm{~mL})$ were added to $5 \mathrm{~mL}$ of complete medium for lymphocyte cultivation PB-Max Karyotyping (Gibco, Thermo Fisher Scientific, Waltham, MA, USA) and incubated at $37^{\circ} \mathrm{C}$ for $72 \mathrm{~h}$. The cytochalasin B (final concen-
Table 1. General demographic parameters of mothers of newborns born 18 years after the environmental contamination.

\begin{tabular}{lc}
\hline \multicolumn{1}{c}{ Parameters } & $\begin{array}{c}\text { Mothers } \\
(\mathrm{n}=22)\end{array}$ \\
\hline Age, years & $28.59 \pm 4.56$ \\
mean \pm SD & $21-36$ \\
Range of variation & \\
Residence & 17 \\
Urban & 5 \\
Suburb & \\
Smoking & 7 \\
Yes & 15 \\
No & \\
Pregnancy & 9 \\
I & 8 \\
II & 5 \\
III & $/$ \\
Diet & $/$ \\
Oral contraception & $/$ \\
Other drug therapy & \\
\hline
\end{tabular}

tration of $4 \mu \mathrm{g} / \mathrm{ml}$; Sigma, St. Louis, MO, USA) was added to the cultures 44 th $\mathrm{h}$ from the beginning of cultivation. After incubation the cells were treated with cold hypotonic $0.56 \% \mathrm{KCl}$ solution. Then the cells were centrifuged and fixed with fixative solution (methanol : glacial acetic acid = 3:1), three times for $15 \mathrm{~min}$ each. The suspended cells were dropped onto clean and cold slides, and then lamp-dried slides were stained with $2 \%$ Giemsa (Alfapanon, Novi Sad, Serbia). A total of 1,000 binucleated (BN) cells per newborn were scored for the $\mathrm{MN}$, using optical microscope (Nikon E50i) at $400 \times$ magnifications.

\section{Statistical analyses}

The SPSS (version 20) software package was used. Results are expressed as mean \pm standard deviation (SD). Differences in $\mathrm{MN}$ frequencies before and after EC were analyzed using the paired sample $t$-test. Differences in MN frequencies between sexes were analyzed using the independent sample $t$-test. The comparisons between groups and within group variances of newborns for research before and after EC were made using one-way analysis of variance (ANOVA). The influences of demographic characteristics of the mothers as well as the sex of the newborns on the MN frequency were analyzed using multiple linear regression analysis. In all comparisons, $p<0.05$ was considered as indicating statistical significance.

\section{Results}

The results of the study are presented in Tables 2-5 and Fig. 1, 2.

Table 2 shows individual values and range of variation of MN frequency in umbilical blood lymphocytes of new- 
Table 2. The individual micronuclei (MN) frequencies in umbilical blood lymphocytes of newborns born 18 years after environmental contamination in Kragujevac.

\begin{tabular}{|c|c|c|c|c|c|c|c|c|}
\hline \multirow{2}{*}{ Newborns } & \multirow{2}{*}{$\begin{array}{l}\text { Age } \\
\text { (day) }\end{array}$} & \multirow{2}{*}{ Sex } & \multirow{2}{*}{$\begin{array}{l}\text { Pregnancy } \\
\text { (weeks) }\end{array}$} & \multirow{2}{*}{$\begin{array}{l}\text { Mother's age } \\
\quad \text { (years) }\end{array}$} & \multirow{2}{*}{$\begin{array}{l}\text { Mothers } \\
\text { smokers } \\
(+/-)\end{array}$} & \multirow{2}{*}{$\begin{array}{c}\text { Frequency of } \\
\text { MN/1,000 } \\
\text { BN cells }\end{array}$} & \multicolumn{2}{|c|}{ Distribution of MN } \\
\hline & & & & & & & $1 \mathrm{MN}$ & $2 \mathrm{MN}$ \\
\hline 1. & 0 & F & 38 & 26 & + & 7 & 7 & 1 \\
\hline 2. & 0 & $\mathrm{~F}$ & 40 & 27 & - & 7 & 7 & 1 \\
\hline 3. & 0 & F & 41 & 30 & - & 8 & 8 & l \\
\hline 4. & 0 & $\mathrm{~F}$ & 40 & 32 & - & 8 & 8 & 1 \\
\hline 5. & 0 & $\mathrm{~F}$ & 40 & 33 & - & 5 & 5 & / \\
\hline 6. & 0 & F & 40 & 34 & - & 6 & 6 & 1 \\
\hline 7. & 0 & $\mathrm{~F}$ & 39 & 29 & + & 4 & 4 & 1 \\
\hline 8. & 0 & F & 40 & 32 & - & 2 & 2 & l \\
\hline 9. & 0 & $\mathrm{~F}$ & 40 & 32 & - & 4 & 2 & 1 \\
\hline 10. & 0 & M & 41 & 22 & - & 7 & 7 & / \\
\hline 11. & 0 & M & 39 & 21 & - & 5 & 5 & l \\
\hline 12. & 0 & M & 40 & 25 & - & 6 & 4 & 1 \\
\hline 13. & 0 & M & 40 & 21 & + & 5 & 5 & l \\
\hline 14. & 0 & M & 40 & 35 & + & 6 & 6 & I \\
\hline 15. & 0 & M & 41 & 31 & - & 7 & 7 & l \\
\hline 16. & 0 & M & 38 & 32 & - & 6 & 4 & 1 \\
\hline 17. & 0 & M & 40 & 28 & - & 6 & 6 & l \\
\hline 18. & 0 & M & 39 & 29 & - & 7 & 5 & 1 \\
\hline 19. & 0 & M & 41 & 22 & + & 1 & 1 & l \\
\hline 20. & 0 & M & 40 & 26 & + & 1 & 1 & 1 \\
\hline 21. & 0 & M & 40 & 36 & + & 2 & 2 & 1 \\
\hline 22. & 0 & $\mathrm{M}$ & 40 & 26 & - & 3 & 3 & 1 \\
\hline $\begin{array}{l}\text { Range of } \\
\text { variation }\end{array}$ & 0 & F-M & $38-41$ & $21-36$ & $+/-$ & $1-8$ & $1-8$ & $0-1$ \\
\hline
\end{tabular}

F, female; M, male; +, smoker; -, non-smoker.

borns born 18 years after the strong EC. MN varied from 1 to $8 / 1,000 \mathrm{BN}$ cells, similarly in neonates of both sexes, 2-8 $\mathrm{MN} / 1000 \mathrm{BN}$ for female and 1-7 MN/1,000 BN cells for male.

The mean MN frequency in umbilical lymphocytes of newborns was $5.14 \pm 2.17 / 1,000 \mathrm{BN}$ cells. Differences in mean $\mathrm{MN}$ frequencies between female $(5.67 \pm 2.06)$ and male $(4.77 \pm 2.24)$ newborns were statistically insignificant $(p=0.345)$. There was no significant difference between the mean $\mathrm{MN}$ frequencies of newborns whose mothers were smokers and non-smokers. Newborns whose mothers were smokers had insignificantly lower mean MN frequency comparing to the newborns of non-smoking mothers (3.71 \pm 2.43 vs. $5.80 \pm 1.74 ; p=0.062$ ) (Table 3 ).

Table 4 shows summarized results of MN frequencies of newborns born before $\mathrm{EC}$, and in four different periods after EC. MN frequency in lymphocytes of newborns born 18 years after EC significantly decreased comparing to the newborns born 12 months after EC $(5.14 \pm 2.17$ vs. $9.36 \pm$ $5.60 ; p=0.002)$, and are insignificantly different in relation to $\mathrm{MN}$ frequencies of newborns born before $\mathrm{EC}(p=0.842)$, 18 months after $(p=0.705)$, and 7 years after $\operatorname{EC~}(p=$ 0.495).
Table 3. Summarized results of micronuclei (MN) frequencies in umbilical blood lymphocytes of newborns born during 2018 .

\begin{tabular}{lc}
\hline \multicolumn{1}{c}{ Characteristics } & Newborns \\
\hline Age (day) $(\mathrm{n}=22)$ & 0 \\
MN frequency/1,000 BN cells (mean $\pm \mathrm{SD})$ & \\
Total MN $(\mathrm{n}=22)$ & $5.14 \pm 2.17$ \\
Range of variation $(\mathrm{n}=22)$ & $1-8$ \\
Newborns whose mothers smokers $(\mathrm{n}=7)$ & $3.71 \pm 2.43$ \\
Newborns whose mothers non-smokers $(\mathrm{n}=15)$ & $5.80 \pm 1.74$ \\
Female newborns $(\mathrm{n}=9)$ & $5.67 \pm 2.06$ \\
Male newborns $(\mathrm{n}=13)$ & $4.77 \pm 2.24$ \\
\hline
\end{tabular}

Distributions of $\mathrm{MN} / 1,000 \mathrm{BN}$ cells in five different periods in umbilical lymphocytes of newborns born in the territory of the City of Kragujevac are shown in Fig. 1. In the last analyzed period, only 113 cells out of the 22,000 total analyzed $\mathrm{BN}$ cells, contained $\mathrm{MN}$. The most common were BN cells with $1 \mathrm{MN}(0.48 \%)$, while cells with $2 \mathrm{MN}$ were much rarer $(0.02 \%)$.

Fig. 2 presents distribution of $\mathrm{MN} / \mathrm{cell} /$ newborn in umbilical lymphocytes of newborns born in the territory of 
Table 4. Summarized results of micronuclei (MN) frequencies of newborns born before and in different periods after environmental contamination (EC) in Kragujevac.

\begin{tabular}{lcccccccc}
\hline \multicolumn{1}{c}{ Sampling period } & $\mathrm{N}$ & $\begin{array}{c}\text { Total } \\
\text { analyzed } \\
\text { cells }\end{array}$ & $\begin{array}{c}\text { Number of } \\
\text { BN cells } \\
\text { with MN }\end{array}$ & $\begin{array}{c}\text { Range of } \\
\text { variation of } \\
\text { MN } \\
\text { frequency/1,000 } \\
\text { BN cells }\end{array}$ & $\begin{array}{c}\text { MN } \\
\text { frequency/1,000 } \\
\text { BN cells } \\
\text { (mean } \pm \text { SD) }\end{array}$ & $p$ values & References \\
\hline Before EC & 25 & 24,070 & 138.36 & $1-13$ & $5.53 \pm 3.02^{\text {a }}$ & a vs.e & 0.842 & Milosevic-Djordjevic et al. (2005) \\
12 months after EC & 22 & 22,000 & 206 & $1-23$ & $9.36 \pm 5.60^{\text {b }}$ & b vs.e & $\mathbf{0 . 0 0 2}$ & Milosevic-Djordjevic et al. (2005) \\
18 months after EC & 14 & 14,000 & 86 & $1-16$ & $6.14 \pm 3.57^{\text {c }}$ & c vs.e & 0.705 & Milosevic-Djordjevic et al. (2005) \\
7 years after EC & 41 & 41,000 & 194 & $0-12$ & $4.73 \pm 3.38^{\text {d }}$ & d vs.e & 0.495 & Milosevic-Djordjevic et al. (2007a) \\
18 years after EC & 22 & 22,000 & 113 & $1-8$ & $5.14 \pm 2.17^{\text {e }}$ & & & Present research \\
\hline
\end{tabular}

BN cells, binucleated cells.

Table 5. Results of one-way analysis of variance (ANOVA) for micronuclei (MN) frequencies of newborns born in different periods in Kragujevac $(\mathrm{n}=$ 123).

\begin{tabular}{lrrrrr}
\hline \multicolumn{1}{c}{ Variance } & Sum of Squares & \multicolumn{1}{c}{ df } & Mean Square & F & $p$ value \\
\hline Between Groups & 329.453 & 4 & 82.363 & 5.974 & 0.000 \\
Within Group & $1,640.703$ & 119 & 13.787 & & \\
Total & $1,970.156$ & 123 & & & \\
\hline
\end{tabular}

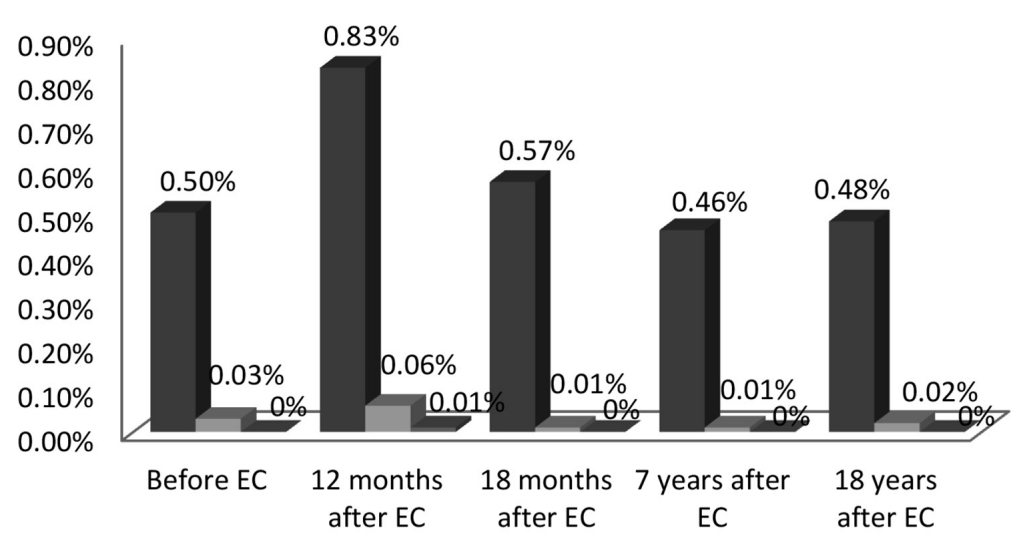

$\square 1 \mathrm{MN}=2 \mathrm{MN}=3 \mathrm{MN}$

Fig. 1. Distribution of micronuclei (MN)/1,000 binucleated cells in five different periods in umbilical lymphocytes of newborns born in the territory of the City of Kragujevac.

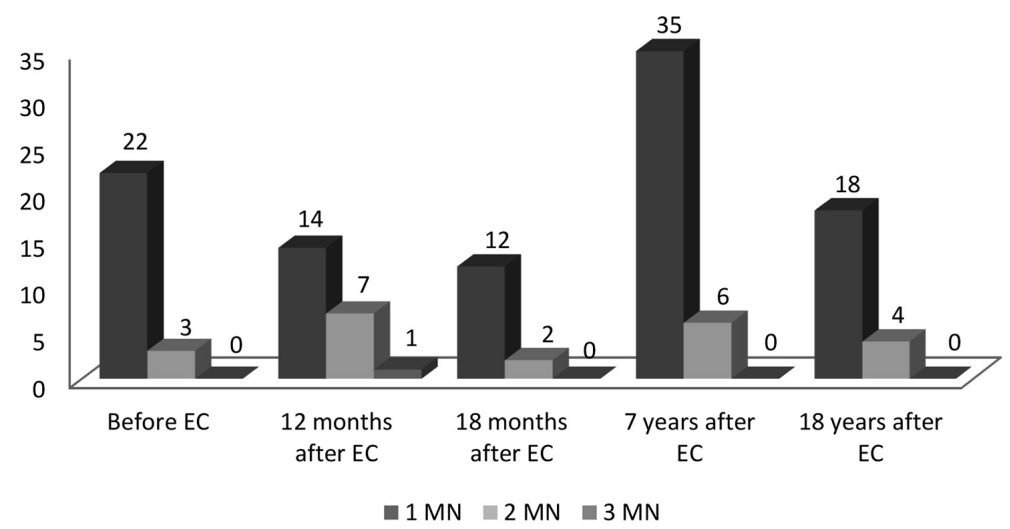

Fig. 2. Distribution of micronuclei (MN)/cell/newborn in umbilical lymphocytes of newborns born in the territory of the City of Kragujevac. 
the City of Kragujevac in five different periods. BN cells with $1 \mathrm{MN}$ were the most frequent, cells with $2 \mathrm{MN}$ were significantly less present as in previous analyzed periods, while cells with $3 \mathrm{MN}$ were not observed in any neonates born in the last analyzed period.

The results of ANOVA are shown in Table 5. The analysis included a total of 123 newborns from five different periods. Between groups and within group variances were significantly different $(\mathrm{F}=5.974 ; p=0.000)$.

Multiple linear regression analysis showed that the mother's age, cigarette smoking ( $<20$ cigarettes/day) and number of pregnancies, as well as sex of the newborns were not predictors of MN frequency in umbilical lymphocytes of babies born during 2018 .

\section{Discussion}

Monitoring and analysis of MN frequency in human peripheral blood lymphocytes are extensively used in epidemiological molecular and cytogenetic studies with the aim to assess the presence of chromosomal damage after exposure to genotoxic agents. When the toxicants are released into the environment, even in low concentrations, they will accumulate and exert their toxic effects on living organisms over a long period of time (Rollin 2011).

It is known that the human fetus reacts to various environmental genotoxicants, which may pass through the placenta and can induce DNA damage (Furnes et al. 2011). So, Sram et al. (2016) have shown that fetuses and children are more sensitive to different environmental toxicants than the adults. One of reasons is that the placenta does not provide absolute protection to the fetus from external influences (Milosevic-Djordjevic et al. 2005; Myren et al. 2007). On the other hand, high proliferative level of fetal cells, decreased immune response, reduced ability of detoxification of carcinogens and lower efficiency of DNA rappers are factors that significantly influence the fetal sensitivity (Rackaityte and Halkais 2020).

The most research on cytogenetic damage in humans has focused on exposures to ionizing radiation (Miyake et al. 2019; Tubic Vukajlovic et al. 2021), heavy metals (Yadav et al. 2019; Husain and Mahmood 2020) and PCBs (Wang et al. 2018). There is not much data on the longterm effects of environmental exposure to contamination PCBs. However, the effect of in utero environmental exposures on health during childhood has gained major public interest. Thus, the aim of this study was to evaluate $\mathrm{MN}$ frequency in umbilical blood lymphocytes of newborns born in Kragujevac, 18 years after the EC due to the bombing of Kragujevac in Central Serbia and strong air, soil and water pollution, as potential indicator of in utero exposure to genotoxic agents. The mean MN frequency in newborns born during 2018 was $5.14 \pm 2.17$, which is significantly less than the $\mathrm{MN}$ frequency 12 months after contamination, and almost not different compared to the MN frequency before contamination. Also, there was no significant difference in mean $\mathrm{MN}$ frequency when comparing results of newborns born 18 years after EC with newborns born 18 months and seven years after EC. Generally, periodical decrease of MN frequency in years after EC corresponds to substantial changes in environment in our city comparing to period of strong pollution. Our previously published results suggested that increased concentrations of environmental agents significantly damaged the genetic material of fetal body cells which we detected as increasing the MN frequency in umbilical blood lymphocytes (MilosevicDjordjevic et al. 2005, 2007a). Stankovic et al. (2004) came to the similar conclusion. They showed a significant increase of MN frequency in newborns born one and two years after the bombing of Serbia, because of high EC and induced stress. Also, other studies found some association between air pollution and MN frequency in newborns (Rossnerova et al. 2011; Stayner et al. 2014). Moller et al. (2014) concluded that genome instability is associated with exposure to air pollution particles and production of reactive oxygen species, which is one of the mechanisms known to induce MN formation (Kirsch-Volders et al. 2014).

The distribution of $\mathrm{MN} /$ cells/newborns in umbilical lymphocytes shows that in the last analyzed period 18/22 $(81.81 \%)$ of the examined newborns contained only $\mathrm{BN}$ cells with $1 \mathrm{MN}$, while $4 / 22$ newborns $(18.19 \%)$ contained BN cells with $2 \mathrm{MN}$, which was 1.2 times more and 1.8 times less compared to the period of 12 months after EC $(14 / 22,63.64 \%$ and $7 / 22,31.81 \%)$. In the last period, no newborn had BN cells with more than $2 \mathrm{MN}$. We noticed that the percentage of $\mathrm{BN}$ cells with $\mathrm{MN}$ decreased almost twice compared to the period 12 months after EC, while it almost did not differ compared to the period before EC. The obtained results indicate that with the reduction of environmental contamination, not only the total percentage of $\mathrm{MN}$, but also the percentage of $\mathrm{BN}$ cells with a larger number of $\mathrm{MN}$ decreased.

Our study revealed that $\mathrm{MN}$ frequencies in umbilical lymphocytes between female and male newborns at birth were not significantly different, which agrees with our previous published results and with other authors as well (Milosevic-Djordjevic et al. 2007b; Sobol and Bezrukov 2007; Holland et al. 2011).

Furthermore, we wanted to investigate whether maternal smoking affects genome instability of newborns. It is known that cigarettes contain many carcinogens such as polycyclic aromatic hydrocarbons, arylmines, N-nitrosamines and aromatic amines (Tsui et al. 2008), but its influence on fetal development and newborn health is not fully investigated. Our results showed that there was no significant difference in MN frequencies between newborns whose mothers were smokers and non-smokers. Also, we showed that newborns whose mothers were smokers had insignificantly lower mean $\mathrm{MN}$ frequency than newborns whose mothers were non-smokers. Such an observation can be explained by increased efficiency of DNA repair due to constant exposure to the mutagen (Chatterjee and Walker 2017). Our results are in agreement with the results of Grujicic et al. 
(2008) and Bennett et al. (2010) who observed that there was no significant difference in the mean MN frequencies in umbilical blood lymphocytes of the newborns of smoking mothers and of non-smoking mothers.

Based on the results obtained in the study, we can conclude that exposure to strong environmental contamination in utero affected genome instability of fetuses. However, gradual improvement of environmental conditions 18 years after strong contamination lead to a decreased MN frequency in umbilical blood lymphocytes of newborns born on the territory of the City of Kragujevac. Sex of newborns, age of mothers, cigarette smoking $(<20$ cigarettes/ day), and number of pregnancies did not affect the MN frequency of the newborns. The general conclusion would be that the genome of umbilical lymphocytes represents a realistic picture of events both inside the body and in the environment.

\section{Acknowledgments}

This work was supported by the Serbian Ministry of Education, Science and Technological Development (Agreement No. 451-03-9/2021-14/200122).

\section{Conflict of Interest}

The authors declare no conflict of interest.

\section{References}

Bakrac, S., Klem, E. \& Milanovic, M. (2018) Assessment of ecological damage from the NATO bombing of the Republic of Serbia in 1999. Vojno Delo, 8, 71-81.

Bennett, L.M., Wang, Y., Ramsey, M.J., Harger, G.F., Bigbee, W.L. \& Tucker, J.D. (2010) Cigarette smoking during pregnancy: chromosome translocations and phenotypic susceptibility in mothers and newborns. Mutat. Res., 696, 81-88.

Chatterjee, N. \& Walker, G.C. (2017) Mechanisms of DNA damage, repair and mutagenesis. Environ. Mol. Mutagen., 58, 235-263.

Dourado, P.L.R., Rocha, M.P., Roveda, L.M., Raposo, J.L.J., Candido, L.S., Cardoso, C.A.L., Morales, M.A.M., Oliveira, K.M.P. \& Grisolia, A.B. (2017) Genotoxic and mutagenic effects of polluted surface water in the midwestern region of Brazil using animal and plant bioassays. Genet. Mol. Biol., 40, 123-133.

Fenech, M. (2007) Cytokinesis-block micronucleus cytome assay. Nat. Protoc., 2, 1084-1104.

Fenech, M. (2020) Cytokinesis-block micronucleus cytome assay evolution into a more comprehensive method to measure chromosomal instability. Genes (Basel), 11.

Furness, D.L., Dekker, G.A. \& Roberts, C.T. (2011) DNA damage and health in pregnancy. J. Reprod. Immunol., 89, 153-162.

Grujicic, D., Milosevic-Djordjevic, O., Arsenijevic, S. \& Marinkovic, D. (2008) Treatment of pregnant women with a betamimetic and verapamil increases the micronuclei frequency in umbilical cord blood lymphocytes. Tohoku J. Exp. Med., 215, 363-371.

Holland, N., Fucic, A., Merlo, D.F., Sram, R. \& Kirsch-Volders, M. (2011) Micronuclei in neonates and children: effects of environmental, genetic, demographic and disease variables. Mutagenesis, 26, 51-56.

Husain, N. \& Mahmood, R. (2020) Taurine attenuates Cr(VI)induced cellular and DNA damage: an in vitro study using human erythrocytes and lymphocytes. Amino Acids, 52,
35-53.

Kirsch-Volders, M., Bonassi, S., Knasmueller, S., Holland, N., Bolognesi, C. \& Fenech, M.F. (2014) Commentary: critical questions, misconceptions and a road map for improving the use of the lymphocyte cytokinesis-block micronucleus assay for in vivo biomonitoring of human exposure to genotoxic chemicals-a HUMN project perspective. Mutat. Res. Rev. Mutat. Res., 759, 49-58.

Milic, J., Curcic, M., Brnjas, Z., Carapina, H., Randjelovic, J., Krinulovic, K. \& Jovovic, A. (2019) The socio-economic impact timeline in Serbia for persistent organic pollutants (POPs). Sci. Total Environ., 688, 486-493.

Milosevic-Djordjevic, O., Grujicic, D., Arsenijevic, S., Brkic, M., Ugrinovic, S. \& Marinkovic, D. (2007a) Micronuclei in cord blood lymphocytes as a biomarker of transplacental exposure to environmental pollutants. Tohoku J. Exp. Med., 213, 231-239.

Milosevic-Djordjevic, O., Grujicic, D., Arsenijevic, S. \& Marinkovic, D. (2005) Monitoring of lymphocyte micronuclei among newborns from Kragujevac in Central Serbia before and after environmental contamination. Tohoku J. Exp. Med., 205, 1-9.

Milosevic-Djordjevic, O., Grujicic, D. \& Marinkovic, D. (2007b) The lack of sex differences in the micronuclei frequency in umbilical cord blood lymphocytes. Korean J. Genet., 29, 51-56.

Miyake, T., Shimada, M., Matsumoto, Y. \& Okino, A. (2019) DNA damage response after ionizing radiation exposure in skin keratinocytes derived from human-induced pluripotent stem cells. Int. J. Radiat. Oncol. Biol. Phys., 105, 193-205.

Moller, P., Danielsen, P.H., Karottki, D.G., Jantzen, K., Roursgaard, M., Klingberg, H., Jensen, D.M., Christophersen, D.V., Hemmingsen, J.G., Cao, Y. \& Loft, S. (2014) Oxidative stress and inflammation generated DNA damage by exposure to air pollution particles. Mutat. Res. Rev. Mutat. Res., 762, 133-166.

Myren, M., Mose, T., Mathiesen, L. \& Knudsen, L.E. (2007) The human placenta--an alternative for studying foetal exposure. Toxicol. In Vitro, 21, 1332-1340.

O'Callaghan-Gordo, C., Fthenou, E., Pedersen, M., Espinosa, A., Chatzi, L., Beelen, R., Chalkiadaki, G., Decordier, I., Hoek, G., Merlo, D.F., Nieuwenhuijsen, M., Roumeliotaki, T., Vafeiadi, M., Vande Loock, K., Kleinjans, J., et al. (2015) Outdoor air pollution exposures and micronuclei frequencies in lymphocytes from pregnant women and newborns in Crete, Greece (Rhea cohort). Environ. Res., 143, 170-176.

Rackaityte, E. \& Halkias, J. (2020) Mechanisms of fetal T cell tolerance and immune regulation. Front. Immunol., 11, 588.

Rollin, H. (2011) Manganese: Environmental pollution and health effects. In Encyclopedia of environmental health chapter, edited by Nriagu, J.O. Elsevier, Burligton, pp. 617-629.

Rossnerova, A., Spatova, M., Pastorkova, A., Tabashidze, N., Veleminsky, M. Jr., Balascak, I., Solansky, I. \& Sram, R.J. (2011) Micronuclei levels in mothers and their newborns from regions with different types of air pollution. Mutat. Res., 715, 72-78.

Santibanez-Andrade, M., Quezada-Maldonado, E.M., OsornioVargas, A., Sanchez-Perez, Y. \& Garcia-Cuellar, C.M. (2017) Air pollution and genomic instability: the role of particulate matter in lung carcinogenesis. Environ. Pollut., 229, 412-422.

Sobol, M.V. \& Bezrukov, V.F. (2007) The micronuclei frequencies in the buccal cell epithelium of young people of different age and gender in Ukraine. Tsitol. Genet., 41, 56-58.

Sram, R.J., Rossner, P. Jr., Rossnerova, A., Dostal, M., Milcova, A., Svecova, V., Pulkrabova, J., Hajslova, J. \& Veleminsky, M. Jr. (2016) Impact of air pollution to genome of newborns. Cent. Eur. J. Public Health, 24 Suppl, S40-S44.

Stankovic, M., Joksic, G. \& Guc-Scekic, M. (2004) Incidence of micronuclei in pregnant women and cord blood samples 
before and after the bombing of Serbia. Arch. Oncol., 12, 200-202.

Stayner, L.T., Pedersen, M., Patelarou, E., Decordier, I., Vande Loock, K., Chatzi, L., Espinosa, A., Fthenou, E., Nieuwenhuijsen, M.J., Gracia-Lavedan, E., Stephanou, E.G., KirschVolders, M. \& Kogevinas, M. (2014) Exposure to brominated trihalomethanes in water during pregnancy and micronuclei frequency in maternal and cord blood lymphocytes. Environ. Health Perspect., 122, 100-106.

Tsui, H.C., Wu, H.D., Lin, C.J., Wang, R.Y., Chiu, H.T., Cheng, Y.C., Chiu, T.H. \& Wu, F.Y. (2008) Prenatal smoking exposure and neonatal DNA damage in relation to birth outcomes. Pediatr. Res., 64, 131-134.

Tubic Vukajlovic, J., Simic, I. \& Milosevic-Djordjevic, O. (2021) DNA and chromosomal damage in peripheral blood lympho- cytes in patients with acute coronary syndrome undergoing a coronary angiography. Anatol. J. Cardiol., 25, 243-249.

UNEP (United Nations Environment Programme) (2000) UNEPled Balkan Task Force to continue its work in Yugoslavia. Feasibility Study. Press Release, HAB/161, UNEP/58. https://www.un.org/press/en/2000/20000208.unep58.doc.html [Accessed: May 17, 2021].

Wang, Y., Sun, X., Fang, L., Li, K., Yang, P., Du, L., Ji, K., Wang, J., Liu, Q., Xu, C., Li, G., Giesy, J.P. \& Hecker, M. (2018) Genomic instability in adult men involved in processing electronic waste in Northern China. Environ. Int., 117, 69-81.

Yadav, B., Vishwakarma, V., Kumar, S., Aggarwal, N.K., Gupta, R. \& Yadav, A. (2019) Antigenotoxic effects of morin against lead induced genomic damage in cultured human peripheral blood lymphocytes. J. Food Biochem., 43, e12883. 